\title{
Parasitic diversity of a wild Satanoperca jurupari population, an ornamental cichlid in the Brazilian Amazon
}

\author{
Marcos TAVARES-DIAS ${ }^{1,4 *}$; Marcos Sidney Brito OLIVEIRA²; Raissa Alves GONÇALVES ${ }^{3}$; \\ Lígia Rigor NEVES ${ }^{4}$ \\ 1 Embrapa Amapá, Macapá, AP, Brasil. \\ 2 Universidade Federal do Oeste do Pará (UFOPA), Programa de Pós-Graduação em Recursos Aquáticos e Continentais Amazônicos (RACAM), Santarém, PA, Brasil. \\ 3 Universidade Nilton Lins, Programa de Pós-Graduação em Aquicultura, Manaus, AM, Brasil. \\ ${ }^{4}$ Universidade Federal do Amapá (UNIFAP), Programa de Pós-Graduação em Biodiversidade e Biotecnologia (PPG-BIONORTE), Macapá, AP, Brasil. \\ * Corresponding author: marcos.tavares@embrapa.br
}

\section{ABSTRACT}

Assessment of biodiversity is fundamental for the understanding of ecological interactions, but fish parasites were neglected in biodiversity estimates for a long time. The aim of this paper was to investigate the diversity of parasites in Satanoperca jurupari in the Amazon River system in Brazil. Of the fish examined, 90.0\% were parasitized by one or more species of protozoans and metazoans, and a total of 3,110,094 parasites were collected. Ichthyophthirius multifiliis, Piscinoodinium pillulare, Sciadicleithum juruparii, Clinostomum marginatum, Posthodiplostomum sp., Genarchella genarchella, Argulus multicolor and Ergasilus coatiarus were found. However, I. multifiliis and P. pillulare were the most prevalent, abundant and dominant parasites, while $A$. multicolor and $G$. genarchella were the least prevalent and abundant parasites. The parasites had an aggregate dispersion, but E. coatiarus and the endoparasite species had a higher aggregation pattern. The species richness of parasites varied from 1 to 8 species per host, the Brillouin index varied from 0.32 to 1.09 and evenness varied from 0.01 to 0.47 . The host size did not influence the diversity indices and the abundance of parasites, which did not affect the body condition of the hosts. Satanoperca jurupari is a new host for G. genarchella.

KEYWORDS: aggregation, Cichlidae, freshwater fish, parasites

\section{Diversidade parasitária de uma população natural de Satanoperca jurupari, um ciclídeo ornamental na Amazônia brasileira}

\section{RESUMO}

A avaliação da biodiversidade é fundamental para a compreensão das interaçôes ecológicas, mas os parasitas de peixes foram negligenciados nas estimativas de biodiversidade durante muito tempo. O objetivo deste trabalho foi investigar a diversidade de parasitos em Satanoperca jurupari do sistema do Rio Amazonas no Brasil. Dos peixes examinados, 90,0\% estavam parasitados por uma ou mais espécies de protozoários e metazoários, e um total de 3.110 .094 parasitos foram coletados. Ichthyophthirius multifliis, Piscinoodinium pillulare, Sciadicleithum juruparii, Clinostomum marginatus, Posthodiplostomum sp., Genarchella genarchella, Argulus multicolor e Ergasilus coatiarus foram os parasitos encontrados. Porém, I. multifliis e P. pillulare foram os parasitos mais prevalentes, abundantes e dominantes, enquanto $A$. multicolor e $G$. genarchella foram os parasitas menos prevalentes e abundantes. Estes parasitas tiveram uma dispersão agregada, mas E. coatiarus e os endoparasitos apresentaram um padrão de agregação mais elevado. A riqueza de espécies de parasitos variou de 1 a 8 espécies por hospedeiro, o índice de Brillouin variou de 0,32 a 1,09 e a uniformidade variou de 0.01 a 0.47 . O tamanho dos hospedeiros não influenciou os índices de diversidade e abundância parasitária, que não afetaram a condição corporal dos peixes. Satanoperca jurupari é um novo hospedeiro para G. genarchella.

PALAVRAS-CHAVE: agregação, Cichlidae, peixes de água doce, parasitos 


\section{INTRODUCTION}

In the Amazon River system, the climatic and topographic diversity, the aquatic biodiversity and the surplus of precipitation are reflected in the large variety of wetlands. Most rivers are accompanied by large fringing floodplains of different shapes and vegetation covers, according to flood regime and regional climate. Consequently, the floodplains are important habitats for various native fish, as they provide feeding and nursery areas. The Amazon basin is a center of diversity for most groups of Neotropical fish, with accordingly high levels of species richness of fish, as well as aquatic invertebrates and macrophytes, which could influence the abundance of parasites in fish. This Amazon River has diverse tributaries draining its water levels, which vary enormously during the year (Albert and Reis 2011; Junk 2013), including the Igarapé Fortaleza hydrographic basin, in the region of the state Amapá (northern Brazil).

The Igarapé Fortaleza basin, an important tributary located in the estuarine coastal sector, is characterized by having a river system with extensive floodplains, constituting physical systems with a clogged river, which is drained by freshwater and connected to a main watercourse, influenced by high rainfall and 12-hour tides from the Amazonas River (TavaresDias et al. 2014). In this tributary of the Amazon River system, there are more than 16 native Cichlidae species among 80 species of freshwater fish (Gama and Halbolth 2004).

Satanoperca jurupari Heckel, 1840 is a cichlid species with a wide distribution in the Amazon River system, in Brazil, Peru, Ecuador, Colombia and French Guyana (Kullander 2003; Froese and Pauly 2016). This ornamental fish is omnivorous and eats microcrustaceans, fruit seeds, grasses and small fish, as well as aquatic and terrestrial insect larvae. Moreover, this is a fish that digs into the muddy substrate looking for food (Froese and Pauly 2016), a behavior that gives it the popular name of earth-eating devilfish. This cichlid can reach $25 \mathrm{~cm}$ in total length, has multiple spawns and parental care, and does not perform migration to reproduce (Santos et al. 2004; Soares et al. 2011; Queiroz et al. 2013; Froese and Pauly 2016). Satanoperca jurupari has been known to be infected by ectoparasites such as Argulus multicolor, Sciadicleithrum satanopercae, Sciadicleithrum edgari, Sciadicleithrum juruparii and endoparasites such as Procamallanus (Spirocamallanus) rarus, Procamallanus (Spirocamallanus) sp., Raphidascaris (Sprentascaris) lanfrediae, Pseudoproleptus sp., Anisakidae gen. sp. and Neoechinorhynchus (Neoechinorhynchus) paraguayensis (Malta 1984; Yamada et al. 2009; Melo et al. 2011a,b; Melo et al. 2012a,b; Paschoal et al. 2016). However, despite its economic importance as an ornamental species, the parasite community of $S$. jurupari has not been studied in detail.

Many parasite species have life cycles that involve transmission through a trophic chain of intermediate and definitive host species. Hence, each parasite species in a parasite community in a host population will reflect the presence of various organisms in the environment that support the parasite's life cycle. Therefore, close interactions between fish host characteristics (size, age, sex, food habit, trophic level, life mode, density, etc.), the environment (temperature, climate, season, etc.), and the level of parasite infection have been well documented in diverse fish species from a variety of habitats (Poulin and Fitzgerald 1987; Rohde et al. 1995; Mamani et al. 2004; Marcogliese et al. 2006; Lopes et al. 2009; Violante-González et al. 2009; Rohlenová et al. 2011; Bittencourt et al. 2014; Tavares-Dias et al. 2014, Alcântara and Tavares-Dias 2015; Chapman et al. 2015). However, there are only a few studies on the parasite communities and diversity in fish from the Amazon. Such studies will increase the knowledge on the rich aquatic biodiversity of this large ecosystem. In this way, this first study investigated the protozoan and metazoan parasite communities of a $S$. jurupari population of a tributary from the Amazon River system, in the north of Brazil.

\section{MATERIAL AND METHODS}

\section{Fish and parasite sampling}

During the period from June 2011 to December 2012, 30 specimens of $S$. jurupari $(12.4 \pm 3.6 \mathrm{~cm}$ and $39.0 \pm 30.4$ g) were collected in the Igarapé Fortaleza basin, in the region of Macapá, in the state of Amapá, northern Brazil (Figure 1), for parasitological analysis. All fish were collected with nets of different meshes $(10-40 \mathrm{~mm})$ and cast nets. The present work was developed according to the principles adopted by the Brazilian College of Animal Experiments (Cobea), with the authorization from Ethics Committee in the Use of Animals of Embrapa Amapá (\#:004 - CEUA/CPAFAP) and ICMBio (\# 23276-1).

The gills, nostrils, opercula and mouth cavity of the fish were examined to ascertain whether any protozoan and metazoan parasites were present. The gastrointestinal tract was removed and examined to collect endoparasites. Previously methodological techniques were used to collect, fix, conserve, count and stain the ectoparasites for identification (Eiras et al. 2006; Justine et al. 2012). Protozoan parasites were counted in a Sedgewick-Rafter counting chamber. To analyze the parasite infracommunities, the ecological terms used were those recommended by Bush et al. (1997).

The following descriptors for the parasite community were calculated: the species richness, the Brillouin diversity index $(H B)$, evenness $(E)$ in association with diversity index, the Berger-Parker dominance index $(d)$ and the dominance frequency (percentage of the infracommunities in which a parasite species is numerically dominant) (Rohde et al. 


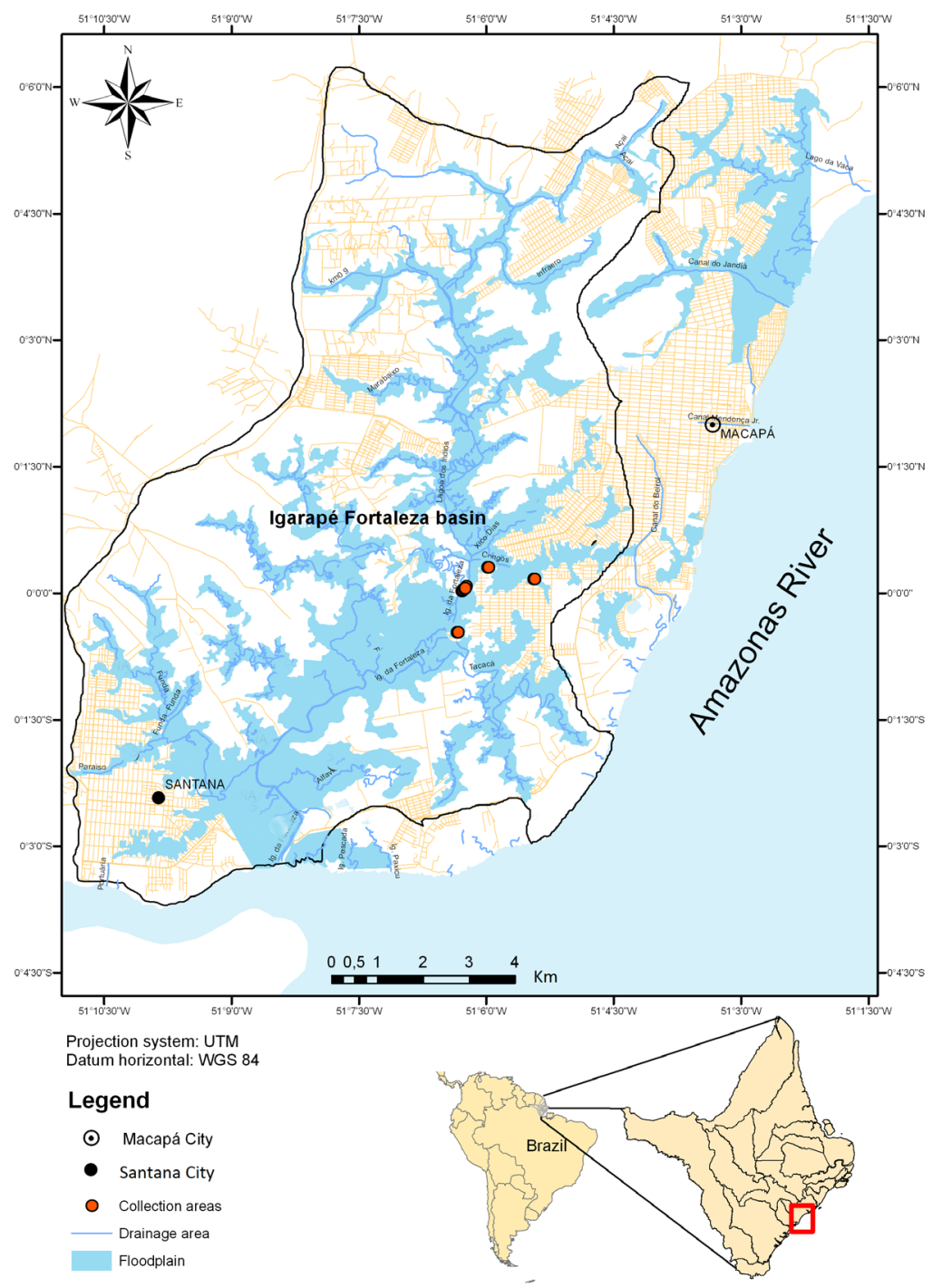

Figure 1. Collection locality of Satanoperca jurupari in Igarapé Fortaleza, a tributary from the Amazon River system, Northern Brazil. This figure is in color only in the electronic version.

1995; Magurran 2004), using the Diversity software (Pisces Conservation Ltd., UK). The variance-to-mean ratio (ID), and the index of discrepancy of Poulin (D) were calculated using the Quantitative Parasitology 3.0 software to detect the distribution pattern of parasite infracommunities (Rózsa et al. 2000) for species with prevalence $>10 \%$. The ID significance for each infracommunity was tested using the $d$-statistics (Ludwig and Reynolds 1988).

All fish were weighed (g) and measured for total length $(\mathrm{cm})$, and then necropsied for parasitological analysis. Body weight $(\mathrm{Wt})$ and total length $(\mathrm{Lt})$ were used to calculate the relative condition factor $(\mathrm{Kn})$ of hosts, which was compared to the standard value $(\mathrm{Kn}=1.00)$ using the t-test. Body weight (Wt) and total length (Lt) were used to calculate the relative condition factor $(\mathrm{Kn})$ of fish and the length-weight relationship ( $\mathrm{W}=\mathrm{aL}^{\mathrm{b}}$ ) after the logarithmic transformation of length and weight and subsequent adjustment of two straight lines, obtaining $\ln y=\ln A+B \ln x($ Le Cren 1951). The Spearman correlation coefficient ( $r s$ ) was used to determine possible correlations of parasite abundance with the length, weight, $\mathrm{Kn}$, the parasite species richness and the Brillouin diversity of the hosts ( $\operatorname{Zar} 2010)$. 


\section{RESULTS}

In this study, $90.0 \%$ of the fish examined had the gills and intestine parasitized by one or more species. A total of 3,110,094 parasites were collected. The parasitic communities consisted of species of Protozoa, Crustacea, Monogenoidea, Acanthocephala, Nematoda and Digenea. However, the protozoans Ichthyophthirius multifiliis (Ciliophora) and Piscinoodinium pillulare (Dinogflagellida) were the most prevalent, abundant and dominant parasites. Among the helminths, Sciadicleithum juruparii (Dactylogyridae), Clinostomum marginatum (Clinostomidae) and Posthodiplostomum (Diplostomidae) were the most prevalent and abundant species, while Genarchella genarchella (Derogenidae) was the least prevalent and abundant species. Among the crustaceans, Argulus multicolor (Argulidae) was the least prevalent and abundant species. Acanthocephalans Gorytocephalus spectabilis (Neoechinorhynchidae) were found in larval and adult stage (Table 1). These main parasites had an aggregated dispersion, which was higher for Ergasilus coatiarus (Ergasilidae) and endoparasites (Table 2).

There was a low species richness of parasites, low Brillouin index and low evenness. Species diversity characterized by the Berger-Parker index expresses the proportional abundance of the most abundant species, i.e. I. multifiliis (Table 3). However, the correlation of length with the Brillouin diversity $(r s=0.331, \mathrm{p}=0.074)$ and parasite species richness $(r s=0.215$, $\mathrm{p}=0.253)$ was not observed. There was predominance of hosts parasitized by 2-6 species (Figure 2).

There was no correlation of fish length with the abundance of $I$. multifiliis ( $r s=0.004, \mathrm{p}=0.981)$, P. pillulare ( $r s=0.214, \mathrm{p}=0.256), S$. juruparii $(r s=0.253, \mathrm{p}=0.177)$, Posthodiplostomum sp. $(r s=0.092, \mathrm{p}=0.629)$, G. spectabilis ( $r s$ $=0.205, \mathrm{p}=0.277)$, Ichthyouris sp. $(r s=0.245, \mathrm{p}=0.192)$ and E. coatiarus ( $r s=0.077, \mathrm{p}=0.685)$. No correlation between the fish weight and the abundance of $I$. multifliiis ( $r s=0.076$, $\mathrm{p}=0.691), P$. pillulare $(r s=0.270, \mathrm{p}=0.175), S$. juruparii $(r s=0.265, \mathrm{p}=0.175)$, Posthodiplostomum sp. $(r s=0.128$, $\mathrm{p}=0.500)$, G. spectabilis $(r s=0.203, \mathrm{p}=0.282)$, Ichthyouris sp. $(r s=0.200, \mathrm{p}=0.287)$ and E. coatiarus $(r s=0.131, \mathrm{p}=$ $0.491)$ was found.

The Kn (1.002 \pm 0.149$)$ of hosts was not different $(t=$ $0.617, \mathrm{p}=0.542)$ from the pattern $\mathrm{Kn}(\mathrm{Kn}=1.00)$, indicating good body condition of the hosts. There was no correlation between host $\mathrm{Kn}$ and the abundance of $S$. juruparii ( $r s=$ 0.163, $\mathrm{p}=0.389), I$. multifliiis $(r s=-.0321, \mathrm{p}=0.083), P$. pillulare $(r s=-0.276, \mathrm{p}=0.140)$, E. coatiarus $(r s=-0.307$, $\mathrm{p}=0.099)$, Posthodiplostomum sp. $(r s=-0.286, \mathrm{p}=0.126)$, G. spectabilis $(r s=-0.022, \mathrm{p}=0.908)$ and Ichthyouris sp. ( $r$ s $=0.248, \mathrm{p}=0.187)$.

The equation of weight (W)-length (L) relationship for this host was $\left.\mathrm{Wt}=0.0146 \mathrm{Lt}^{3.0442}, \mathrm{r}^{2}=0.969\right)$, with isometry, indicating a proportional increase of body weight and length.

Table 1. Infracommunities of parasites in Satanoperca jurupari from Igarapé Fortaleza, Eastern Amazon (Brazil). P: Prevalence, MI: Mean intensity, MA: Mean abundance, SI: Sites of infection.

\begin{tabular}{|c|c|c|c|c|c|}
\hline Parasites & $\mathrm{P}(\%)$ & $\mathrm{Ml}$ & MA & Range & $\mathrm{SI}$ \\
\hline Ichthyophthirius multifiliis Fouquet, 1866 & 76.7 & $13,3749.1$ & $102,540.97 \pm 274,405.5$ & $644-1,106,872$ & Gills \\
\hline $\begin{array}{l}\text { Piscinoodinium pillulare Schäperclaus, } \\
\text { 1954, Lom, } 1981\end{array}$ & 60.0 & 1678.8 & $1007.3 \pm 3094.6$ & $16-14,821$ & Gills \\
\hline $\begin{array}{l}\text { Sciadicleithum juruparii Yamada et al., } \\
2009\end{array}$ & 50.0 & 52.9 & $26.5 \pm 49.2$ & $1-154$ & Gills \\
\hline $\begin{array}{l}\text { Posthodiplostomum Dubois, } 1936 \\
\text { (metacercariae) }\end{array}$ & 33.3 & 263.1 & $87.7 \pm 257.5$ & $1-1031$ & Gills \\
\hline $\begin{array}{l}\text { Posthodiplostomum Dubois, } 1936 \\
\text { (metacercariae) }\end{array}$ & 6.7 & 1.5 & $0.1 \pm 0.4$ & $1-2$ & Intestine \\
\hline $\begin{array}{l}\text { Clinostomum marginatum Rudolphi, } 1819 \\
\text { (metacercariae) }\end{array}$ & 10.0 & 1.7 & $0.2 \pm 0.5$ & $1-2$ & Gills \\
\hline $\begin{array}{l}\text { Genarchella genarchella Kohn \& } \\
\text { Fernandes,1988 (metacercariae) }\end{array}$ & 3.3 & 5.0 & $0.2 \pm 0.9$ & $0-5$ & Intestine \\
\hline Ichthyouris Inglis, 1962 (larvae) & 20.0 & 5.7 & $1.1 \pm 4.1$ & $1-21$ & Intestine \\
\hline $\begin{array}{l}\text { Gorytocephalus spectabilis Machado- } \\
\text { Filho, } 1959\end{array}$ & 23.3 & 18.6 & $4.3 \pm 14.2$ & $4-75$ & Intestine \\
\hline Argulus multicolor Stekhoven, 1937 & 6.7 & 1.0 & $0.07 \pm 0.3$ & $1-1$ & Gills \\
\hline Ergasilus coatiarus Araújo \& Varella, 1998 & 20.0 & 7.0 & $1.4 \pm 3.8$ & $1-17$ & Gills \\
\hline
\end{tabular}


Table 2. Dispersion Index (ID), Statistic- $d$ and discrepancy index (D) for the ectoparasite infracommunities of Satanoperca jurupari from Igarapé Fortaleza, Eastern Amazon (Brazil). FD: Frequency of dominance.

\begin{tabular}{lcccc}
\hline Species parasites & ID & d & D & FD (\%) \\
\hline Ichthyophthirius multifiliis & 3.521 & 2.55 & 0.474 & 0.989 \\
Piscinoodinium pillulare & 2.655 & 4.86 & 0.581 & 0.001 \\
Sciadicleithum juruparii & 3.741 & 7.18 & 0.648 & 0.0003 \\
Posthodiplostomum sp. (gills) & 2.525 & 5.55 & 0.739 & 0.0008 \\
Gorytocephalus spectabilis & 2.293 & 3.98 & 0.798 & - \\
Ichthyouris sp. & 1.724 & 2.45 & 0.819 & - \\
Ergasilus coatiarus & 2.473 & 4.43 & 0.825 & - \\
\hline
\end{tabular}

Table 3. Descriptors of diversity for parasite communities of Satanoperca jurupari from Igarapé Fortaleza, Eastern Amazon (Brazil).

\begin{tabular}{lcc}
\hline Diversity indices & Mean \pm SD & Range \\
\hline Species Richness of parasites & $3.0 \pm 2.3$ & $1-8$ \\
Brillouin $(H B)$ & $0.24 \pm 0.33$ & $0.32-1.09$ \\
Evenness $(E)$ & $0.11 \pm 0.14$ & $0.01-0.47$ \\
Dominance of Berger-Parker $(d)$ & $0.88 \pm 0.15$ & $0.49-1.00$ \\
\hline
\end{tabular}

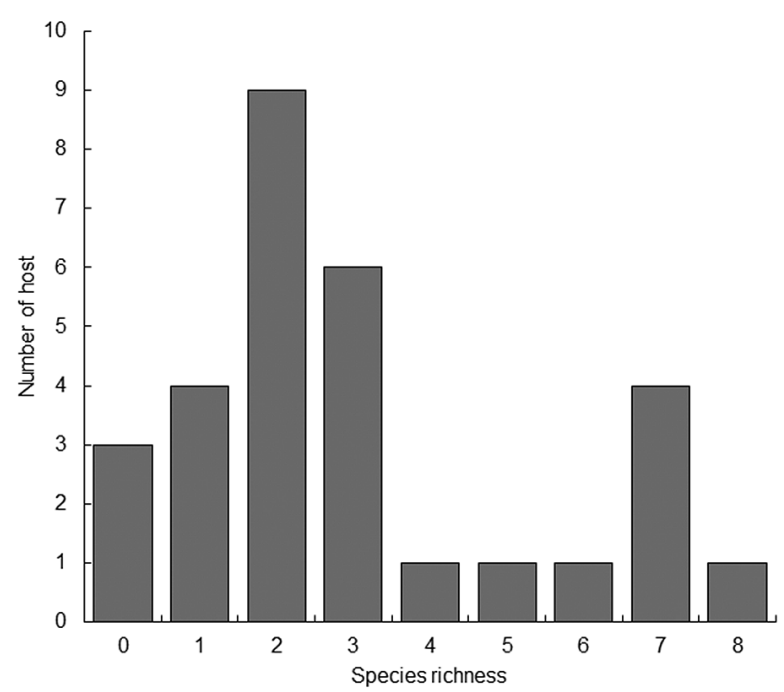

Figure 2. Species richness of ectoparasites in Satanoperca jurupari from Igarapé Fortaleza, Eastern Amazon (Brazil).

\section{DISCUSSION}

Fish populations act as hosts for a large number of parasitic taxa with varied strategies in their life cycle, whether direct or indirect (Poulin and Fitzgerald 1987; Rohde et al. 1995; Mamani et al. 2004; Marcogliese et al. 2006; Lopes et al. 2009; Violante-González et al. 2009; Rohlenová et al. 2011; Bittencourt et al. 2014; Tavares-Dias et al. 2014, Alcântara and Tavares-Dias 2015; Pinto et al. 2015; Chapman et al. 2015). The presence of a great diversity of parasites depends on the host species and on other factors related to the host and environment. Satanoperca jurupari in this study presented a diverse community of ectoparasites belonging to seven protozoan and metazoan species (two Protozoa, two Crustacea, one Monogenoidea and two Digenea), as well as four endoparasite species (one Acanthocephala, one Nematoda and two Digenea), which had an aggregated dispersion. Therefore, at both the component and infracommunity levels, a low diversity of helminths was found in S. jurupari. Similarly, a diversity of ectoparasite and endoparasite communities were reported for Aequidens tetramerus (Tavares-Dias et al. 2014), a cichlid species from the same region of the current study. Omnivorous fish as these two cichlid species occupy a low position in the food web, thereby presenting a low diversity of endoparasites.

Variations in endoparasite communities and diversity may be determined by variables such as a shift in host diet or the volume of food consumed, ontogenetic changes in immunocompetence, modification in the probability of contact with and infection efficiency of potential intermediate hosts, and parasite life-history strategies. Moreover, parasites and intermediate host invertebrates may respond to environmental changes in different ways from individual to community and infracommunity level (Poulin and Fitzgerald 1987; Rohde et al. 1995; Violante-González et al. 2009; Rohlenová et al. 2011; Tavares-Dias et al. 2014, Alcântara and Tavares-Dias 2015; Pinto et al. 2015; Chapman et al. 2015). Therefore, most of these factors may be related to the community structure of parasites in our population of $S$. jurupari.

Most ectoparasite species were found at high prevalence and low mean abundance of infection in $S$. jurupari. Due to the complex relationship between parasites and the environment, initially the parasite attempts to establish itself in the host while the latter resists the infection via its defense mechanisms. Consequently, host susceptibility and resistance will determine whether the infection becomes established or not. Changes in parasite abundance with monoxenic life cycle have been generally considered to be influenced by both the environment and biotic factors (Poulin and Fitzgerald 1987; Rohde et al. 1995; Marcogliese et al. 2006; ViolanteGonzález et al. 2009; Rohlenová et al. 2011; Tavares-Dias et al. 2014, Alcântara and Tavares-Dias 2015). For example, monogeneans and protozoans are good indicators of water quality, because they typically infest fish gills and skin, and are exposed to the environment throughout their monoxenic life cycle (Tavares-Dias et al. 2014; Chapman et al. 2015; Alcântara and Tavares-Dias 2015). Our results indicate that the species composition and species richness of ectoparasites were higher than those for endoparasites. In addition, these 
latter parasites showed a low prevalence and abundance. Two biotic factors may have influenced such infection levels of endoparasites: environmental fluctuations variations and the intermediate host availability (microcrustaceans and snails), which may lead to alterations in the recruitment processes of allogenic species. Seasonal variations in feeding and behavior of $S$. jurupari may have also influenced this recruitment of endoparasites species.

Digeneans are parasites with direct and indirect transmission, and their recovery in a host population can indicate multiple ecosystem and environmental characteristics, such as changes in food-web dynamics, intermediate host invertebrate populations and densities, and water quality (Chapman et al. 2015). Moreover, metacercariae may dominate the metazoan parasite fauna of forage fish populations (Marcogliese et al. 2006). In S. jurupari, Posthodiplostomum metacercariae were the digenean ectoparasites with relatively higher prevalence and abundance than digenean endoparasites C. marginatum, G. genarchella and Posthodiplostomum sp. Moreover, there was a low prevalence and abundance of acanthocephalans G. spectabilis and nematodes Icthyouris sp. These digenean, nematode and acanthocephalan species have also parasitized other cichlid species of the region (Bittencourt et al. 2014; Tavares-Dias et al. 2014), except G. genarchella. The transmission of these parasites, both in active and passive transmission forms, is by means of the availability of primary intermediate hosts (snails or crustaceans). The food source of S. jurupari consists of microcrustaceans, fruit seeds, grasses, small fish, aquatic and terrestrial insect larvae (Santos et al. 2004; Soares et al. 2011; Queiroz et al. 2013; Froese and Pauly 2016), besides snails. Therefore, the preferred food items of S. jurupari may favor the acquisition of these helminthes in the area. Although information on primary intermediate host populations (snails and crustaceans) was not included as a variable in this study, our data are sufficient to provide insights into the potential effect of these invertebrates on host-parasite-environment systems, as has been previously suggested by various studies (Marcogliese et al. 2006; Lopes et al. 2009; Violante-González et al. 2009; Rohlenová et al. 2011; Tavares-Dias et al. 2014, Alcântara and Tavares-Dias 2015; Chapman et al. 2015).

Satanoperca jurupari had relatively high prevalence and low abundance of E. coatiarus, ergasilid ectoparasites that infect freshwater cichlids (Luque et al. 2013; Tavares-Dias et al. 2015). However, A. multicolor has no parasitic specificity, because it is a common branchiuran species infecting many fish from the Amazon River system (Luque et al. 2013; Tavares-Dias et al. 2015). Low prevalence and abundance of A. multicolor were also reported for Pseudoplatystoma punctifer and Pseudoplatystoma tigrinum (Mamani et al., 2004; Lopes et al. 2009). However, Araújo and Varella (1998) described a higher prevalence and abundance of E. coatiarus for Cichla monoculus. Although many branchiurans and ergasilid species are known by their frequent switching of hosts, due to low host specificity, there are other factors that may also influence this parasite-host relationship more than phylogenetic similarity, e.g., ecological factors such as behavior and life style of the host (Mamani et al. 2004; Tavares-Dias et al. 2015).

The body size of the host population has been widely used to determine its influence on parasitic ecological and community descriptors, due to their negative or positive correlation with these factors (Rohde et al. 1995; Mamani et al. 2004; Lopes et al. 2009; Tavares-Dias et al. 2014; TavaresDias et al. 2015). For S. jurupari, there was an absence of the body size correlation with the ecological and community descriptors, as well as with the parasite abundance. This may be an indication that the length and body mass of this host, do not in fact exert an influence over the variation of the parasite infracommunities, as also reported for other hosts (Poulin and Fitzgerald 1987; Alcântara and Tavares-Dias 2015).

\section{CONCLUSIONS}

The component community of S. jurupari was characterized by low species richness, low uniformity and high diversity of parasites. The infracommunities of parasites were not influenced by the host size and showed an aggregate dispersion pattern. Therefore, the main factors structuring the parasite infracommunities were the same ones responsible for structuring the component community. These factors are the hosts feeding behavior and availability of infective forms, which structured the infracommunities of endoparasites through the accumulation of digenean metacercariae, nematode larvae, and acanthocephalans. Moreover, this fish is both an intermediate and definitive host for helminths. The presence of digenean larvae suggests that this host fish is part of the diet of fish at the top of the food web, as well as of aquatic birds that eat fish.

\section{ACKNOWLEDGMENTS}

Dr. M. Tavares-Dias was granted a Research fellowship (\# 303013/2015-0) from the National Council for Scientific and Technological Development (CNPq, Brazil). L.R Neves and M.S.B. Oliveira were granted a scholarship from CNPq.

\section{REFERENCES}

Albert, J.S.; Reis, R.E. 2011. Introduction to Neotropical freshwaters. In: Albert, J.S.; Reis, R.E. (Ed). Historical biogeography of Neotropical freshwater fishes. University of California Press, Berkeley, p.3-19.

Alcântara, N.M; Tavares-Dias, M. 2015. Structure of the parasite communities in two Erythrinidae fish from Amazon River system (Brazil). Brazilian Journal of Veterinary Parasitology, 24: 183-190. 
Araújo, C.S.; Varella, A. 1998. Ergasilus coatiarus sp. n. (Copepoda, Poecilostomatoida, Ergasilidae) parasita dos filamentos branquiais de Cichla monoculus Spix, 1831 (Perciforme: Cichlidae) da Amazônia brasileira. Acta Amazonica, 28: 417-424.

Bittencourt, L.S.; Pinheiro, D.A.; Cárdenas, M.Q.; Fernandes, B.M.M.; Tavares-Dias, M. 2014. Parasites of native Cichlidae populations and invasive Oreochromis niloticus (Linnaeus, 1758) in tributary of Amazonas River (Brazil). Brazilian Journal of Veterinary Parasitology, 23: 44-54.

Bush A.O., Lafferty K.D., Lotz J.M., Shostack A.W. 1997. Parasitology meets ecology on its own terms: Margolis et al. revisited. The Journal of Parasitology, 83: 575-583.

Chapman, J.M.; Marcogliese, D.J.; Suskic, C.D.; Cooke, S.J. 2015. Variation in parasite communities and health indices of juvenile Lepomis gibbosus across a gradient of watershed land-use and habitat quality. Ecological Indicators, 57: 564-572.

Eiras, J.C.; Takemoto, R.M.; Pavanelli, G. 2006. C. Métodos de estudo e técnicas laboratoriais em parasitologia de peixes. Eduem, Maringá, 199p.

Froese, R.; Pauly, D. (Ed.). 2016. FishBase. World wide web electronic publication. (www.fishbase.org). Accessed on $15 / 06 / 2016$.

Gama, C.S.; Halboth, D.A. 2004. Ictiofauna das ressacas das bacias do Igarapé da Fortaleza e do Rio Curiaú. In: Takiyama, L.R.; Silva, A.Q. (Org.). Diagnóstico das ressacas do estado do Amapá: bacias do Igarapé da Fortaleza e Rio Curiaú, Macapá-AP. CPAQ/ IEPA e DGEO/SEMA, p.23-52.

Junk, W.J. 2013. Current state of knowledge regarding South America wetlands and their future under global climate change. Aquatic Sciences, 75: 113-131.

Justine, J.L.; Marine J. Briand, M.J.; Bray, R.A. 2012. A quick and simple method, usable in the field, for collecting parasites in suitable conditions for both morphological and molecular studies. Parasitology Research, 111: 341-351.

Kullander, S.O. 2003. Cichlidae (Cichlids). In: Reis, R.E.; Kullander, S.O.; Ferraris Jr., C.J. (Ed.). Checklist of the freshwater fishes of South and Central America. EDIPUCRS, Porto Alegre, p.605-654.

Le Cren, E.D. 1951. The length-weight relationship and seasonal cycle in gonadal weight and condition in the perch (Perca fluviatilis). Journal of Animal Ecology, 20: 201-219.

Lopes, L.P.C.; Varella, A.M.B.; Malta, J.C.O. 2009. Metazoan parasites of Pseudoplatystoma punctifer (Linnaeus, 1766) and Pseudoplatystoma tigrinum (Spix and Agassiz, 1829) (Siluriformes: Pimelodidae) of the central Amazon basin, Brazil. Biologia Geral Experimental, 9: 3-15.

Ludwig, J.A.; Reynolds, J.F. 1988. Statistical ecology: a primer on methods and computing. Wiley-Interscience Pub, New York, 337p.

Luque, J.L.; Vieira, F.M.; Takemoto, R.M.; Pavanelli, G.C.; Eiras, J.C. 2013. Checklist of Crustacea parasitizing fishes from Brazil. Check List, 9: 1449-1470.

Magurran, A. E. 2004. Measuring biological diversity. Blackwell Science, Oxford, UK, 256p.
Malta, J.C.O. 1984. Os peixes de um lago de várzea da Amazônia Central (Lago Janauacá, Rio Solimôes) e suas relaçôes com os crustáceos ectoparasitas (Branchiura: Argulidae). Acta Amazonica, 14: 355-372.

Mamani, M.; Hamel, C.; Van Damme, P.A. 2004. Ectoparasites (Crustacea: Branchiura) of Pseudoplatystoma fasciatum (surubí) and $P$. tigrinum (chuncuina) in Bolivian white water floodplains. Ecología en Bolivia, 39: 9-20.

Marcogliese, D.J; Gendron, A.D; Plante, C.; Fournier, M.; Cyr, D. 2006. Parasites of spottail shiners (Notropis hudsonius) in the St. Lawrence River: effects of municipal effluents and habitat. Canadian Journal of Zoology, 84: 1461-1481.

Melo, M.F.; Giese, E.G.; Santos, J.N.; Portes-Santos, C. 2011 a. First record of Pseudoproleptus sp. (Nematoda: Cystidicolidae) in fish host. Acta Tropica, 117: 212-215.

Melo, M.F.; Santos, J.N.; Giese, E.G.; Santos, E.G.N.; PortesSantos, C. 2011b. Raphidascaris (Sprentascaris) lanfrediae sp. nov. (Nematoda: Anisakidae) from the fish Satanoperca jurupari (Osteichthyes: Cichlidae). Memórias do Instituto Oswaldo Cruz, 106: 553-556.

Melo, M.F.C.; Santos, E.G.N.; Giese, E.G.; Santos, J.N.; PortesSantos, C. 2012a. Parasites of Satanoperca jurupari (Osteichthyes: Cichlidae) from Brazil. Parasitology Research, 110: 389-394.

Melo, M.F.C.; Santos, Santos, J.N.; Portes-Santos, C. 2012b. Sciadicleithrum juruparii n. sp. (Monogenea: Ancyrocephalidae) from the gills of Satanoperca jurupari (Heckel) (Osteichthyes: Cichlidae) in the Guamá River, Amazon Delta, Brazil. Systematic Parasitology, 82: 125-129.

Paschoal, F.; Scholz, T.; Tavares-Dias, M.; Luque, J.L. 2016. Dactylogyrids (Monogenea) parasitic on cichlids from northern Brazil, with description of two new species of Sciadicleithrum and new host and geographical records. Acta Parasitologica, 61: 158-164.

Pinto, H.A.; Caffara, M.; Fioravanti, M.L.; Melo, A.L. 2015. Experimental and molecular study of cercariae of Clinostomum sp. (Trematoda: Clinostomidae) from Biomphalaria spp. (Mollusca: Planorbidae) in Brazil. The Journal of Parasitology, 101: 108-113.

Poulin, R.; Fitzgeraldg, G. J. 1987. The potential of parasitism in the structuring of a salt marsh stickleback community. Canadian Journal of Zoology, 65: 2793-2798.

Queiroz, L.J.; Torrente-Vilara, G.; Hoara, W. M.; Pires, T.H.S.; Zuanon, J.; Doria, C.R. C. 2013. Peixes do Rio madeira. $3^{\mathrm{a}} \mathrm{ed}$. v. 2. Dialeto Latin American Documentary, São Paulo, 416p.

Rohde, K.; Hayward, C.; Heap, M. 1995. Aspects of the ecology of metazoan ectoparasites of marine fishes. International Journal of Parasitology, 25: 945-970.

Rohlenová, K.; Morand, S.; Hyršl, P.; Tolarová, S.; Flajšhans, M.; Šimková, A. 2011. Are fish immune systems really affected by parasites? An immunoecological study of common carp (Cyprinus carpio). Parasites and Vectors, 4: 1-18.

Rózsa, L.; Reiczigel, J.; Majoros, G. 2000. Quantifying parasites in samples of hosts. The Journal of Parasitology, 86: 228-232. 
Santos, G.M.; Mérona, B.; Juras, A.A.; Jégu, M. 2004. Peixes do baixo Rio Tocantins: 20 anos depois da Usina Hidrelética Tucuruí. Eletronorte, Brasília, 216p.

Soares, M.G.M.; Costa, L.; Siqueira-Souza, F.; Anjos, H.D.B.; Yamamoto, K.C.; Freitas, C.E.C. 2011. Peixes de lagos do Médio Rio Solimóes. 2a ed. Instituto Piatam, Manaus, 176p.

Tavares-Dias, M.; Oliveira, M.S.B.; Gonçalves, R.A.; Silva, L.M.A. 2014. Ecology and seasonal variation of parasites in wild Aequidens tetramerus, a Cichlidae from the Amazon. Acta Parasitologica, 54: 158-164.

Tavares-Dias, M.; Dias-Júnior, M.B.F.; Florentino, A.C.; Silva, L.M.A.; Cunha, A.C. 2015. Distribution pattern of crustacean ectoparasites of freshwater fish from Brazil. Brazilian Journal of Veterinay Parasitology, 24: 136-147.
Violante-González, J.; Aguirre-Macedo, M.L.; Rojas-Herrera, A.; Guerrero, S.G. 2009. Metazoan parasite community of blue sea catfish, Sciades guatemalensis (Ariidae), from Tres Palos Lagoon, Guerrero, Mexico. Parasitology Research, 105: 997-1005.

Yamada, F.H.; Takemoto, R.M.; Bellay, S.; Pavanelli, G.C. 2009. Two new species of Sciadicleithrum (Monogenea, Dactylogyridae) parasites of Neotropical cichlid fishes from Paraná River, Brazil. Acta Parasitologica, 54: 6-11.

Zar, J.H. 2010. Biostatistical analysis. $5^{\text {th }}$ ed. Prentice Hall, New Jersey, 944p.

Received: 05/09/2016

Accepted: 22/12/2016 